\title{
高さ情報を利用した航空写真からの建物の自動抽出手法
}

\section{Automated Building Extraction from Aerial Photographs in 3D Space}

\author{
史 中超*・柴崎亮介* \\ Zhongchao SHI, Ryosuke SHIBASAKI
}

\begin{abstract}
An effective automated building extraction method by integrating both the feature-based and area -based stereo matching is addressed in this paper. This new technique aims to improve the efficiency and reliability of the building extraction method introduced in vol. 34, no. 5 of this magazine writen by the authors, in which $3 \mathrm{D}$ regions based building extraction model was proposed. In this paper, three other building extraction models based on regions, 3D lines and the results of area-based stereo matching are put forward besides former 3D region based model.
\end{abstract}

\section{1.はじめに}

著者らは領域や線分などのステレオマッチングを用 いた建物の自動抽出方法を提案した1)。その方法の基 本は左右ステレオ写真から抽出された閉じたポリゴン (領域)を用いてステレオマッチングを行い，地面より 高い $3 \mathrm{D}$ 領域として建物の屋根を発見する方法であっ た。しかし，隠蔽やノイズの影響で左右の写真におい て全ての屋根を領域として検出することは容易ではな い。また，屋根を左右の写真で閉じたポリゴンとして 検出できても，マッチングの精度などの影響でそれら は建物の屋根であると判断できない場合もある。その ため，単純な $3 \mathrm{D}$ 領域だけに基づく方法より検出率を 一層向上させることは容易ではない。

本研究では文献 1 ) で紹介された建物検出手法の検 出率を向上させるために，3 D 領域だけではなく, 領 域一線分ペアや 3 Dライン（線分ペア）も利用して建 物の検出を行う。また，本稿では面積相関によるマッ チングの結果を用いて建物検出の信頼性を高める方法 も提案する。

\footnotetext{
*東京大学生産技術研究所

「写真測量とリモートセンシング」VOL. 36，NO. 2， 1997

\section{2. $3 \mathrm{D}$ 領域に基づく建物検出手法の摘要}

著者らが既に発表した建物自動認識手法は大きく， 次の部分からなっている(図 1 を参照)。

（1）ウェーブレット変換による画像の多重解像度分 解 (multi-resolution decomposition) と特徵の検出 (feature extraction) : ガウシアン関数を利用して エッジとコーナーの検出を行った。

(2) 画像セグメンテーション (image segmentation：閉じる領域を抽出する領域分割手法 (MOBIS) を提案し，八フ変換を利用した線分検出手法を検討し た。

（3）特徵に基づくステレオマッチング方法の検討： 領域と線分それぞれの属性（例えば，領域の面積や線 分の向きなど）を利用したマッチング方法とマッチン グ曖昧さの解決方法を提案・検討した。

（4）地面高さの推定：3 Dライン（線分ペア）の空 間高さ (視差)の投票により地面高さの推定を行った。

（5）領域ペア（3 D 領域）から建物の屋根の検出：

$3 \mathrm{D}$ 空間で地面より一定程度高い領域ぺアを建物の屋 根とした。

この手法は複雑な航空写真の場合（隠ぺいが多い場 合など）には高い抽出率に達することが困難であると いう久点がある。というのはすべての屋根を左右の写 


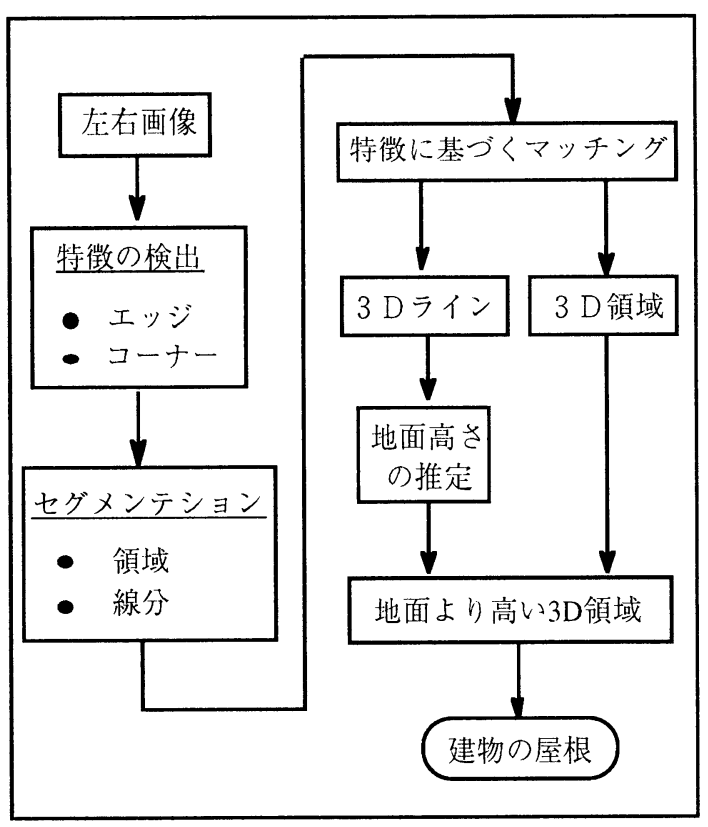

図 13 D 領域に基づく建物検出法の流れ

真とも閉じた領域として検出することが非常に難しい からである。また, 同一の建物の屋根が左右の写真か ら閉じた領域として検出されていても，ステレオマッ チングによりその二つの領域が必ず対応させられると は限らない。従って，それに対して改善必要がある。

\section{3. 面積相関と特徵に基づくマッチングの 組み合わせによる建物検出システム}

\section{1 システムの構成}

通常, 隠ぺいや屋根の色や濃淡の不均一性の影響で, 屋根に関する領域分割の結果は以下の三つのケースが あると考えられる(四 2 を参照)。

- ケース 1 : 写真ペアの両方とも領域として抽出 できる。

- ケース 2 : 写真ペアの一枚からしか閉じる領域 として抽出できない。

• ケース 3 : 写真ペアの両方とも閉じる領域とし て抽出できない。

文献 1 )では，ケース 1 だけを考慮して，建物の自動 検出を行ったが，建物の検出率がそれほど高くないこ とが欠点であった。それを改善するため，ケース 2 と ケース 3 も考えるべきである。図 3 はケース $1 ， 2$ ，

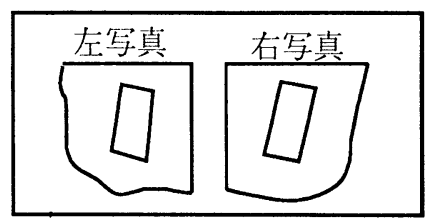

(a) ケース 1：両方とも領域

として抽出できる場合。

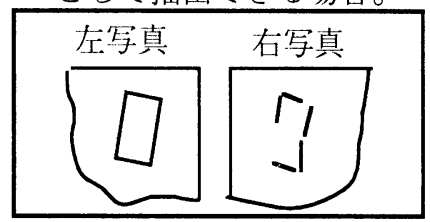

(b) ケース 2:一枚の写真でのみ 領域として抽出できる場合。

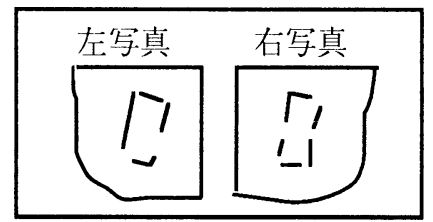

(c) ケース 3：両方とも領域と

して検出できない場合。

図 2 屋根に対する領域分割結果の例

3 の全てを考慮した建物自動検出システムの流れであ る。そのうち,特徵の検出や特徵に基づくステレオマッ チング法などは著者らが既に提案されたシステム（文 献 1)）と同じものであるので，本論文では省略する。 また，本研究で行った面積相関ステレオマッチングは 伝統的な相関関数法と違いはないため，これも本論文 では省略する（文献 5 )を参照)。以下に本システムの 中心となった建物の検出モデルを紹介する。

\section{2 建物の検出モデル}

ここでは, 様々な状況に応じた建物の検出方法を「検 出モデル」と呼ぶ。

\subsection{1 モデル 1 一建物の屋根が左右写真で光れぞれ 領域として抽出できる場合}

モデル 1 の方法は著者らが既に提案した方法である (文献 1))。

\section{2 .2 モデル 2 及びモデル 3 一建物の屋根が片方の} 写真でのみ領域として抽出された場合

領域分割により建物が片方の写真からのみ閉じた領 域として抽出された場合には，もしその片方の写真か ら抽出した単一の領域の $3 \mathrm{D}$ 空間に拀ける高さが分か れば，その高さと地面の高さとを比較することによっ 


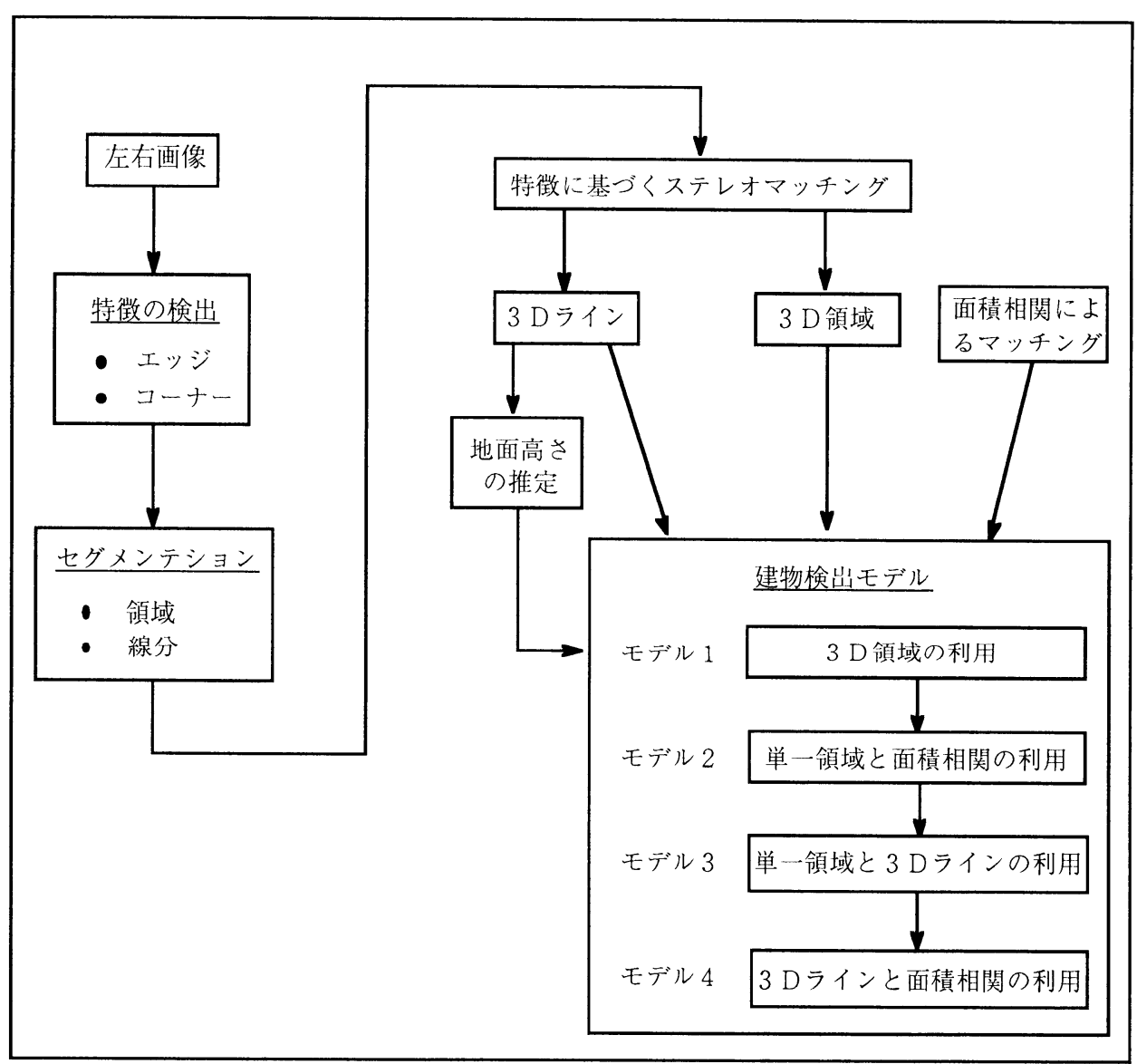

図 3 面積相関と特徵に基づくマッチングを利用した建物自動検出の方法（建物検出モデル）

て建物の屋根かそうではないかと簡単に判断できるは ずである。単一領域の空間高さは以下の二つの方法か ら推定できると思えわれる。

（1）面積相関による単一領域の空間高さの推定法 (モデル2)

まず，面積相関手法によりステレオ写真内の高さの 分布を求める。

次に，単一領域を面積相関マッチングによる高さの 分布と重ね合わせる。

さらに，単一領域内の全てのピクセル $(N$ とする $)$ のうち, 地面から一定程度（例えば 2 メトル以上） 高いピクセルを数える $(n$ とする)。このとき, $n / N>T$ を満たす単一領域を屋根として検出する。ここで, $T$ 閾值は経験值である。なお, 実験では $T$ が 80 パーセン トであれば，単一領域が建物の屋根である可能性が十 分高いことが分かった。
最後に，極端な高さを持っているピクセルを除いた ピクセルの高さの平均值を屋根の高さとする。ここで, 極端な高さを持っているピクセルとは平均高さから大 きくずれているピクセルである。

(2) 3 D ラインによる単一領域の空間高さの推定法 (モデル3)

特徵に基づくステレオマッチング(文献 1 ))により, 既に 3 D ラインの空間高さが分かっているため, 図 4 に示すように単一領域を 3 D イインと対応させ，対応 された全ての 3 Dラインの高さの平均值を単一領域の 空間高さとする（四中細い線と太い線はそれぞれ領域 と 3 Dラインを表示したのである)。

\section{2 .3 モデル 4 一建物が両写真において領域として 検出されない場合}

両方とも領域として検出できなかった場合（ケース 3 の場合)，3 Dラインを一定の条件により 3 D空間で 


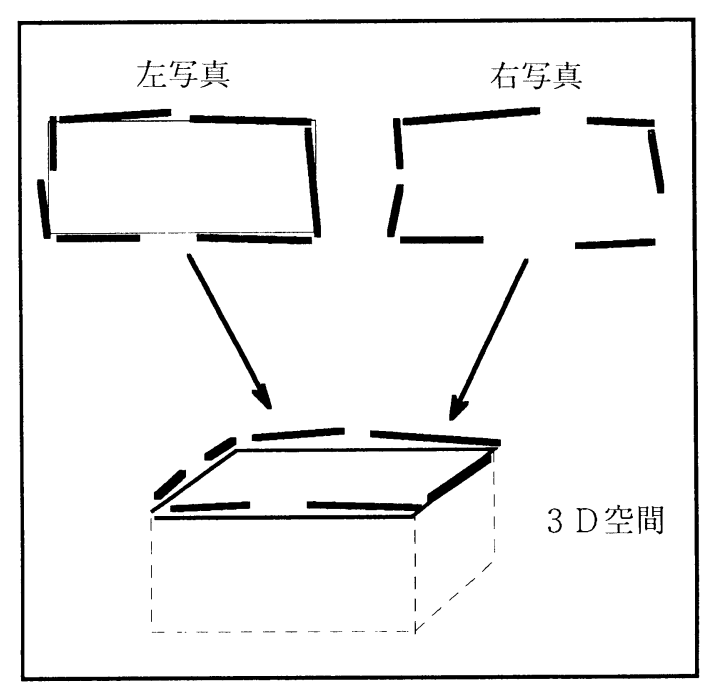

図4３Ｄラインを用いた領域高さの推定法

グループ化（つまり，領域化）させ，グループ化され た領域の空間高さと地面の高さとの比較により建物を 検出する。ここで, 領域化する際に, 以下の条件を満 たさなければならない。

・隣接する 3 Dラインの空間高さがほぼ同じであ ること。

- 隣接する $3 \mathrm{D}$ ラインは平行または垂直でなけれ ばならないこと。平行の場合には, 線分の zero-crossing 記号が同じでなければならない。また, 実際の作業 では以上の条件を満たす組み合わせが多いため，本モ デルではモデル 2 と同様に面積相関の結果を利用して 建物かそうではないかと再確認する必要がある。この
ような再確認は建物検出の信頼性を向上させる。

\section{2 .4 モデルの適用手順}

本システムでは，四 3 に示したようにモデルを順番 適用し，建物の検出を行う。

モデル 1 ：地面より高い $3 \mathrm{D}$ 領域を建物とする；

モデル 2 : モデル 1 から残った領域を面積相関の結 果と重ねあわせ，重なる面積が閾值（例えば $80 \%$ ）よ り大きい領域を建物として検出する；

モデル 3 ：モデル $1 ， 2$ から残った領域を 3 Dライ ンと対応させ，地面より高い単一領域を建物とする；

モデル 4 ：隣接の 3 Dラインを領域化(グループ化) させ，領域化された $3 \mathrm{D}$ ライングループの空間高さが 地面より高ければ，それを建物として検出する。

\section{4. 実験結果}

本稿で利用されたテストデータは $1 / 5000$ 縮尺の航空 写真である。その画像ぺア $(1000 \times 1000)$ の立体視で は180軒の建物が判読できた。前述した四つのモデルを 順番に実行させ，建物自動検出の実験を行った。その 結果の一部分を汹 5 に示す。また, 各モデルの検出率 などを表 1 に表す。ここで, 建物の屋根の全体の半分 以上が検出できれば, 検出されたと数えている。また, 建物の屋根が，いくつかの独立した建物の候補として 検出された場合には，まとめて一つとしている。本実 験では, 四つのモデルで総数181個建物の候補が検出さ れたが，そのうち8軒は建物ではないものが建物とし て検出されてしまった。本実験の建物の検出率は (181-8)/180で，約96パーセントであった。なお， 7

表 1 面積相関と特徵に基づくステレオマッチングによる建物検出実験の統計結果 （立体視では180軒の建物がある）

\begin{tabular}{|c|c|c|c|c|c|c|c|}
\hline & \multirow{2}{*}{$\begin{array}{l}\text { モデル } 1 \\
\text { ( } 3 \text { D 領域 })\end{array}$} & \multicolumn{2}{|c|}{$\begin{array}{c}\text { モデル } 2 * * \\
\text { (領域と面積相関) }\end{array}$} & \multicolumn{2}{|c|}{$\begin{array}{c}\text { モデル } 3^{* *} \\
\text { (領域と } 3 \mathrm{D} \text { D イン) }\end{array}$} & \multirow{2}{*}{$\begin{array}{l}\text { モデル } 4^{* *} \\
\text { ( } 3 \text { D } \\
\text { と面棈相関) }\end{array}$} & \multirow{2}{*}{ 合計 } \\
\hline & & 左写真 & 右等真 & 左等真 & 右写真 & & \\
\hline $\begin{array}{l}\text { 検出された* } \\
\text { 建物候補の数 }\end{array}$ & $51+78$ & $23+130$ & $15+148$ & $3+2$ & $2+4$ & $3+6$ & 181 \\
\hline $\begin{array}{c}\text { 建物ではない } \\
\text { 候補の数 }\end{array}$ & 2 & 2 & 3 & 0 & 0 & 1 & 8 \\
\hline
\end{tabular}

* 結果表示の $\mathrm{a}+\mathrm{b}$ では， $\mathrm{a}$ は屋根が笎全に検出された建物の数であり，b屋根が半分または部分的 に検出された建物の数である。

**モデル $2 ， 3 ， 4$ の結果は同一の建物の屋根が左右写真から同時に検出された場合である。また， 全てのモデルにおいて建物の屋根がいくつかの独立した建物の候補として検出された場合には，ま とめて一つとする。 

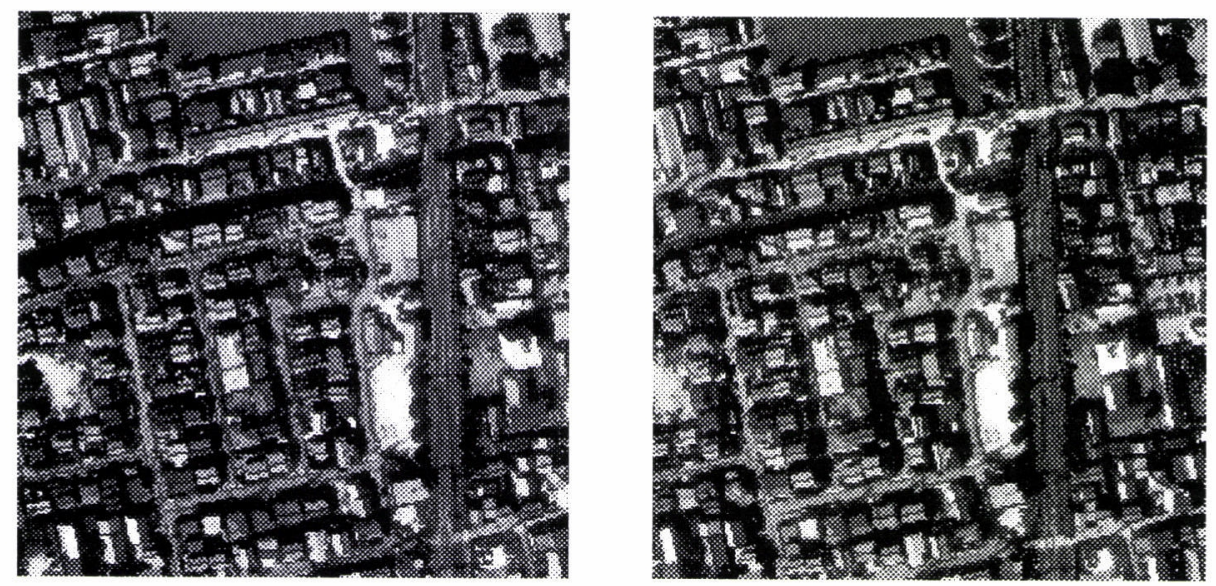

（a）航空写真（立体視では180軒の建物が含まれる）
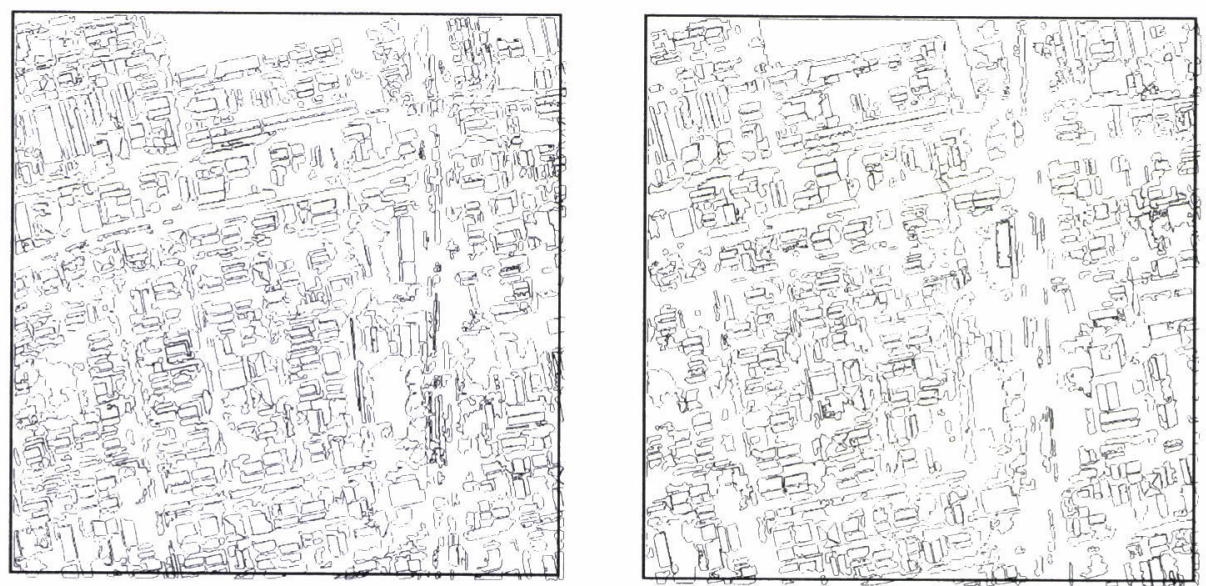

(b) 分割された領域
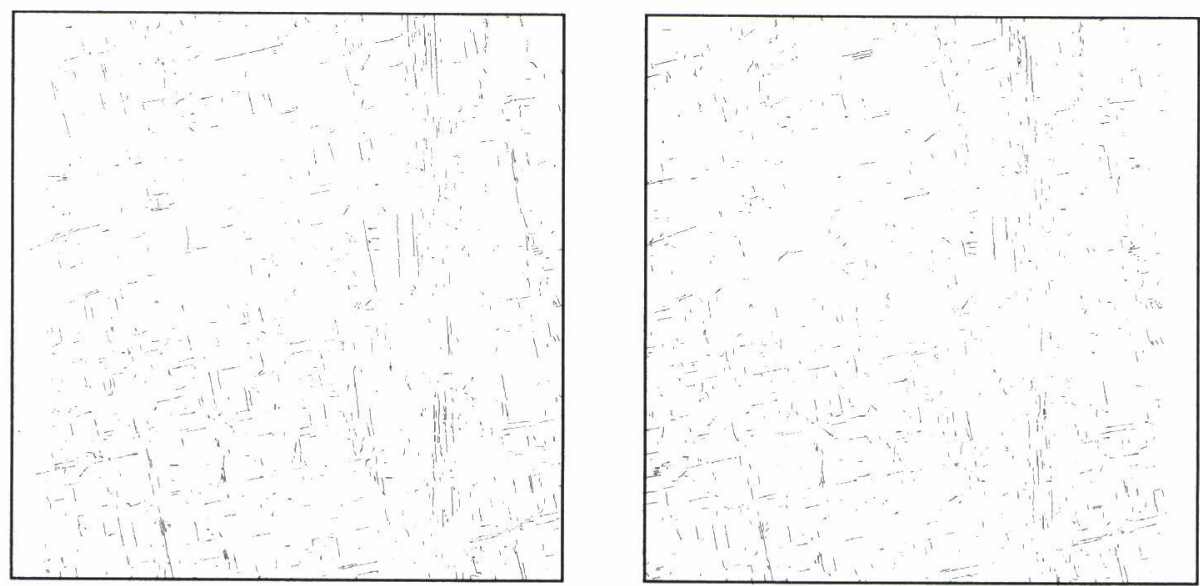

(c) 投票により地面を構成する3 Dライン 

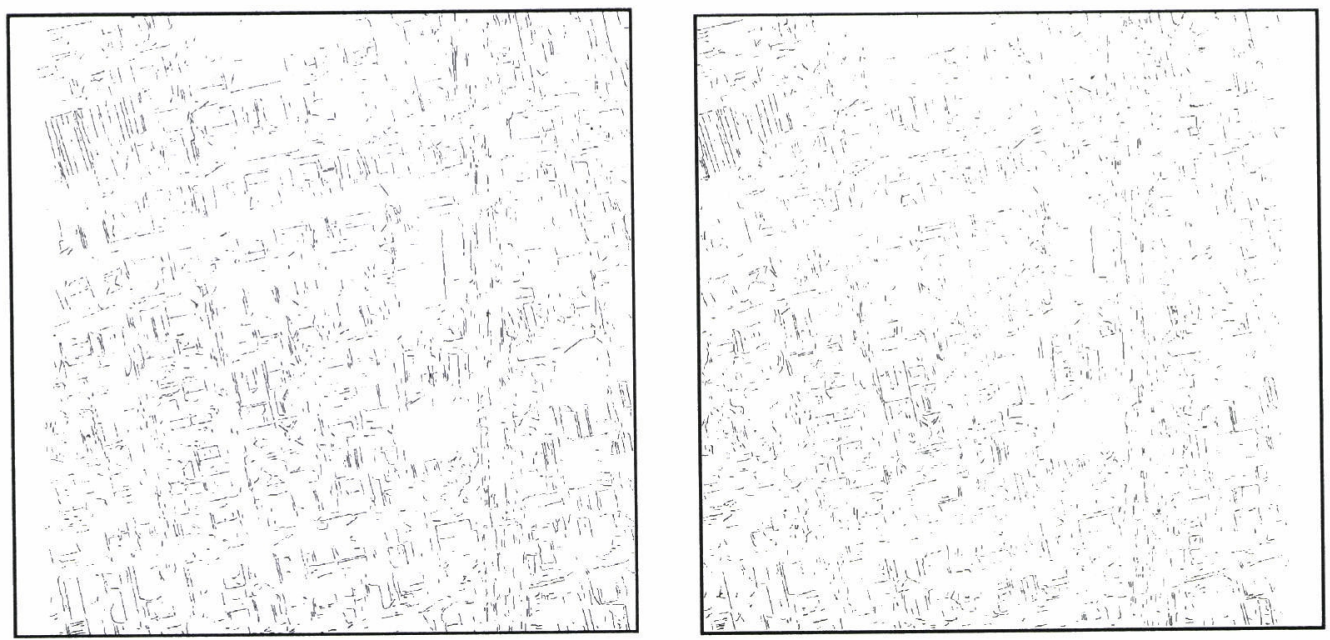

(d) 地面より高い3 D インン
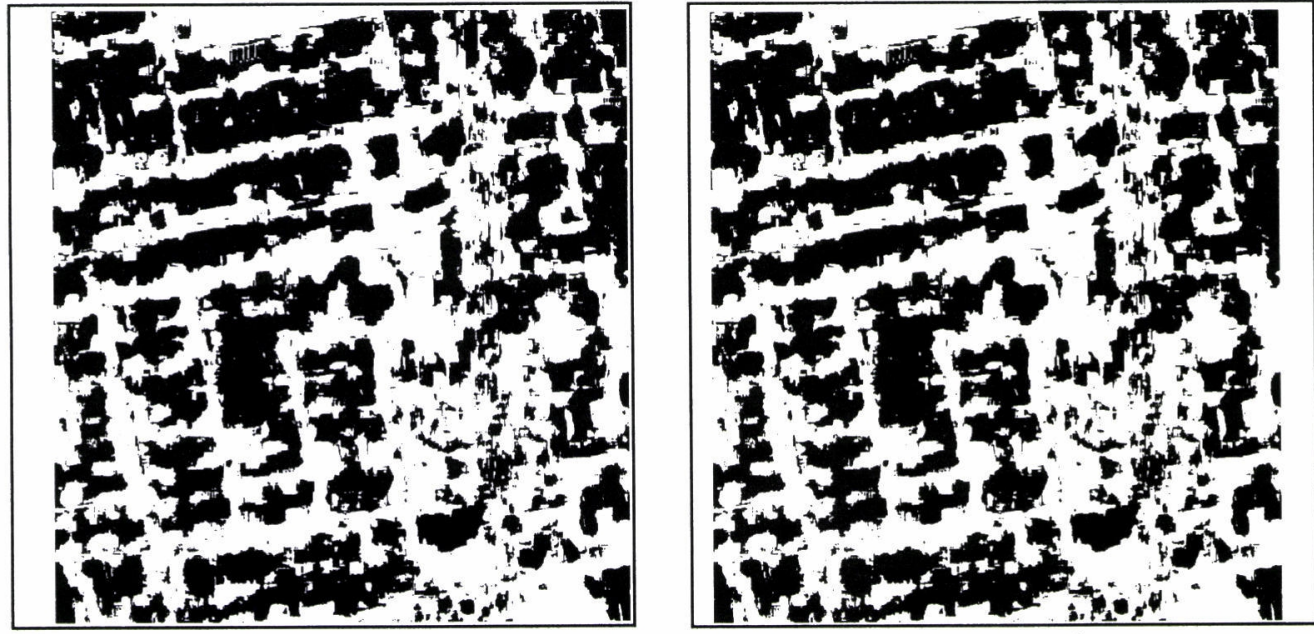

(e) 面積相関によるマッチングの結果（黒は地面より高いピクセル）
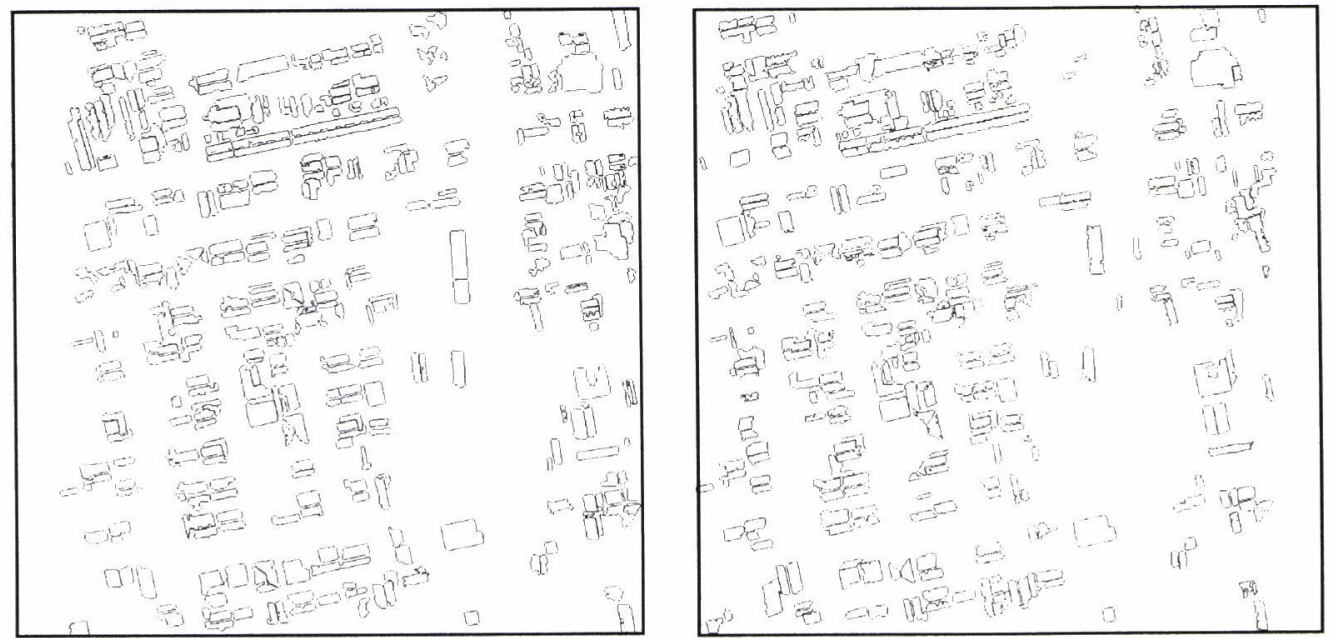

(f) 検出された建物候補

図 5 高さ情報を利用した建物自動検出の実験例 
軒の建物は抽出もれであった。また, この実験の結果 によると, 複雑な画像の場合や単に $3 \mathrm{D}$ 領域を利用し て建物検出を行う場合, 建物の検出率はあまり高くな いことが確認できた（本実験では129/180であった）。

\section{5.まとめ}

本稿では，面積相関と特徵に基づくステレオマッチ ング法により $3 \mathrm{D}$ 空間で効率的に建物の自動検出手法 を提案した。本手法は, $3 \mathrm{D}$ 領域の他, 単一領域や 3 Dライン，面積相関によるステレオマッチングの結果 のそれぞれの組み合わせにより 4 種類の自動検出モデ ルからなっている。実験の結果によると, 複雑な航空 写真に対しても，本手法によって高い検出率で建物を 検出することができる。また，実験の結果では， $3 \mathrm{D}$ ラインを利用したモデル 4 による建物検出について は，それほど検出数が多くなく，改善の可能性がある と思われる（それは本実験で建物検出漏れの主な原因 であった)。モデル 4 の改善は今後の課題として残って いる。また，検出された「建物」と実際の建物との形 状にくい違いがあっても，検出したと判定している。 そのため, 建物の滅失や新築はそれぞれ検出できるも のの, 滅失した後, ただちに新築され, 古い建物の代
わりに新しい建物が建っている場合には十分適用でき ない。こうした限界を緩和することも今後の課題であ る。（受付日1997.1.13，受理日1997.3.7)

\section{参考文献}

1 ）史中超, 柴崎亮介, 高木方隆,「ウェーブレット変 換による画像分割とステレオマッチングを利用した 航空写真からの建物の自動検出の試み」, 写真測量と リモートセンシング学会誌 vol. 34, no. 5, 1995, pp. $36-44$ 。

2) McKeown, D. M., "Information fusion in cartographic feature extraction from aerial imagery," in: Digital Photogrammetric Systems, Wichmann, 1991, pp. 103-110.

3 ) Z. C. Shi and R. Shibasaki, "Wavelet transform supported image segmentation," Proc. of the 15th ACRS, vol. II, Bangalore, India, 1994, pp. 1-3-1 to 1-3-6.

4) Y. T. Liow, T. Pavlidis, "Use of shadows for extracting buildings in aerial images," CVGIP, vol. 49, 1990.

5 ）高木幹雄, 下田陽久,「画像解析ハンドブック」, 東京大学出版会, 1991。 